\title{
FOIX-ALAJOUANINE SYNDROME
}

\section{Case report}

\author{
Kelly C. Bordignon 1 , María Belén Montú2, Ricardo Ramina³, Walter Oleschko Arruda4
}

\begin{abstract}
In a 52-year-old woman, spinal arteriovenous malformation (AVM) has been associated with what has been known as Foix-Alajouanine syndrome. The pathophysiology of the AV fistula is probably related to increased venous pressu refrom the AVM plus thrombotic process. The most common initial symptoms are sensory disturbance, pain and leg weakness. Definitive diagnosis of spinal AVMs requires radiographic demonstration of the vascular anomaly. Nevertheless, in this case, suggestive defects of malformations could not be seen, in contrast to the MRI findings and macroscopical and anatomical-pathological lesion. These findings rise our attention, about the need to keep in mind the clinical suspicion of AVM in cases of back pain and motor deficit, and an early surgical conduct in this situation.
\end{abstract}

KEY WORDS: paraplegia, AV fistula, venous thrombosis.

Síndrome de Foix-Alajouanine: relato de caso

RESUMO - Em mulher de 52 anos, malformação artério-venosa medular (MAV) associava-se com a síndrome de Foix-Alajouanine. A fisiopatologia da fístula artéria-venosa provavelmente está relacionada com a p ressão venosa aumentada, a partir da MAV associada com o processo trombótico. Os sintomas iniciais mais comuns são distúrbio sensorial, dor e fraqueza do membro inferior. O diagnóstico definitivo de MAV medular requer evidências radiográficas da anomalia vascular. De qualquer modo, neste caso, defeitos sugestivos de malformações não foram detectados, contrastando com os achados de ressonância magnética e lesões macroscópicas e anátomo-patológicas. Estes resultados chamaram a atenção e excluíram outras causas. A alta suspeita clínica de MAV nos levou a uma conduta cirúrgica precoce em benefício do paciente.

PALAVRAS-CHAVE: paraplegia, fistula AV, trombose venosa.

In 1926, Foix and Alajouanine described a subacute myelopathy produced by a thrombotic process of the spinal cord that ultimately caused death' 1 . At autopsy, they discovered necrosis of the spinal cord and numerous thickened tortuous vessels lying on the surface of the cord. Years later, in 1931, Lhermitte et al., recognized this process as been associated with a spinal arteriovenous malformation (AVM) ${ }^{2}$. It was generally believed that the rapidly progressive myelopathy resulted from thrombosis of this abnormal vessel within the spinal cord. Consequently, this p rocesss, which came to be known as the Foix-Alajouanine syndrome (FAS), was felt to be irreversible and to carry a poor prognosis ${ }^{3,4}$. In most patients with this condition, sensory symptoms, pain and leg weakness are the most common initial symptoms ${ }^{5-7}$.

A FAS case, submitted to surgery is described, and literature is reviewed about this clinical entity.

\section{CASE}

A 52-year-old woman developed lumbar pain irradiating to the left entire leg after a physical effort (going upand-down in a ladder several times). This pain with a radicular pattern of $\mathrm{S} 1$ was followed by pro g ressive worseni$\mathrm{ng}$ of the pain and progressive leg weakness. After 3 months of conservative treatment (rest, analgesics), she developed a sudden spontaneous and severe low back pain with paresthesias in both legs that rapidly evolved to flaccid paraplegia, with sphincters dysfunction (urinary retention) and complete reflex loss, resembling spinal shock. She had a previous medical history of arterial hypertension. Neurological examination showed a flaccid arreflexic paraplegic patient, with sensory level loss at $\mathrm{S1}$, and urinary retention. Babinski sign was absent. Laboratory tests included both serological and immunological tests: herpes simplex I/II (ELISA), cytomegalovirus (ELISA), VDRL, FTA-abs, hepatitis $B$, antinuclear antibodies, complement $(C 3, C 4), \alpha 1$ glycoprotein, ANCA-p, ANCA-c, and HTLV-I/II.

\footnotetext{
Instituto de Neurologia de Curitiba, Curitiba PR, Brazil: ${ }^{1}$ Resident of Neurosurgery; ${ }^{2}$ Postgraduation in Neurology; ${ }^{3}$ Neurosurgeon,
} ${ }^{4}$ Neurologist.

Received 22 June 2004, received in final form 17 November 2004. Accepted 15 January 2005.

Dra. Kelly C. Bordignon - Rua Jeremias Perretto 300 - 81210-3110 Curitiba PR - Brazil. E-mail: arruda@inc-neuro.com.br 


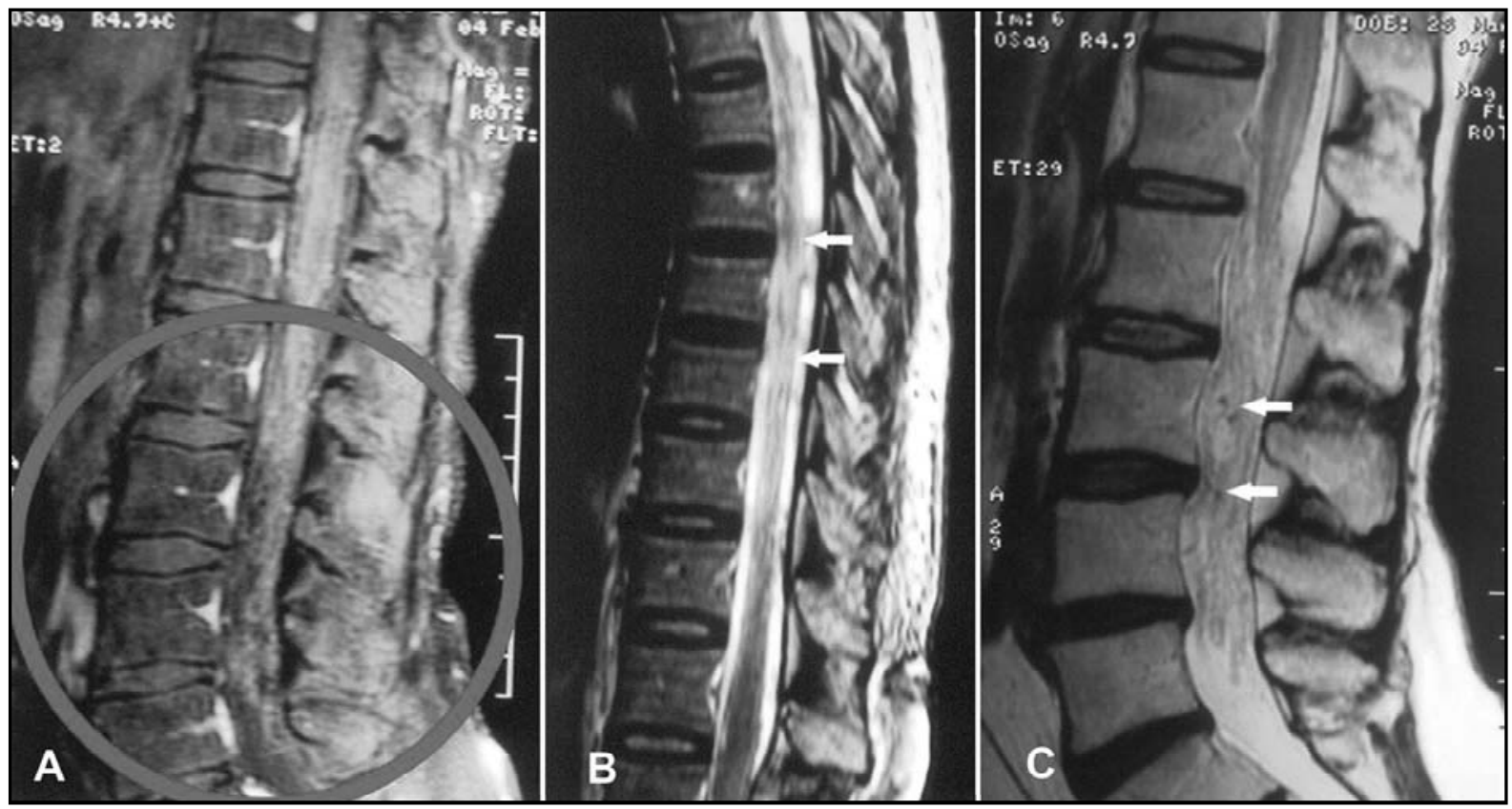

Fig 1. A) Lombosacral T1-weighted with gadolinium MRI shows tortuous vessels involving the caudal equina spinal roots with conus medullaris contrast enhancement (circle). B) T2-weighted thoracic MRI depicts low-density and decreased diam eter of the spinal cord(white arrows), in keeping with ischemic infarcts at several levels. C) Lombosacral MRI . Hemossiderin deposits can be seen (white arrows), probably secondary to previous hemorrhage among the spinal roots.

A lumbar cerebrospinal fluid (CSF) was perfo rmed and showed increased protein (154 mg/dL), 144 red cells $/ \mathrm{mm}^{3}$, with normal white cells $\left(2 / \mathrm{mm}^{3}\right)$ counting. All immunological tests were negative.

Lumbar spine MRI showed changes in keeping with multiple abnormal vascular structures at the low portion of the spinal cord (cone medullaris and cauda equina). Hemosiderosis could be seen at the surface of the cone region, probably due to previous hemorrhage. A hyperintensive signal of the conus medullaris (T2-weighted images) with heterogeneous slight Gd-enhancement (T1-weighted images) was observed. (Figuras $1 \mathrm{~A}, \mathrm{~B}, \mathrm{C}) \mathrm{A}$ spinal arteriography was immediately performed and did not disclose any vascular abnormalities (e.g. spinal AV fistula) and the Adamkievicz artery was not seen.

A laminectomy (L1 to L4) was performed and showed e $\mathrm{n}$ l a roed tortuous red vessels involving the spinal roots. Among those abnormal vessels, a black thrombosed dural AV fistula was identified. The vessel was intradurally divided, and the dural AV fistula was coagulated and excised. Pathological analysis confirmed a thrombosed AV fistula, without evidence of vasculitis.

The rewas no control arteriography at the post-operative period. The patient presented very mild recovery of weakness and sensibility after 3 months of follow-up. A control post-operative spinal MRI showed ischemic lesion of the conus medullaris.

\section{DISCUSSION}

Rosemblum et al. ${ }^{8}$ compared dural AV fistulas and intradural AVM in 81 patients. He described that the clinical and physiopathological aspects in both conditions are different. In intradural AVM, $50 \%$ present in an acutely form, and hemorrhage commonly accompanies this acute clinical deterioration. The high flow of these intradural malformations and the arterial flow steal from eloquent areas complete the pathological mechanism. Acute neu rological deterioration may be also due to spontaneous hemorrhage from AVM. On the other hand, dural AV fistulas typically cause progressive myelopathy and only $10-15 \%$ present an acute $p$ resentation. They are low-flow fistulas, draining intradurally into the coronal venous plexus, which becomes tortuous and elongated with time. A pathophysiological event - venous congestion of spinal cord - results from absence of valves between coronal venous plexus and intramedullary veins, resulting in venous medullary outflow impaiment. Venous congestion is also reflected by a delayed venous phase on angiography. There fore, the lowflow aspect plus venous congestion predisposes to venous thrombosis as final event.

Foix- Alajouanine syndrome has distinctive featu res such as sub acute/acute pro $g$ ressive myelopathy, and absence of hemorrhage in a patient with a spinal AVM. This syndrome is not a distinct enti- 
ty but a complication of spinal AVM that was caused by thrombosis within the abnormal vessels of the spinal cord. This is the end-stage of a sub-acute myelopathy due to venous congestion of the spinal cord. Criscuolo et al. ${ }^{6}$ reasserted this mechanism based on their previous case reports. The symptoms of subacute myelopathy are paraparesia, paresthesias, spasticity, and urinary hesitancy. These symptoms can be enhanced or exacerbated by Valsalvalike manoeuvers. Recently, a case report buttressed the association between spinal AVM and acute episodes of paraplegia caused by singing ${ }^{9}$. The diagnosis of dural AV fistulas can be made by MRI that, typically, shows swelling of medullary conus and slight central spinal enhancement. Our patient presented similar image alterations with additional serpentine vessels involving the spinal roots.

The suspected diagnosis of spinal dural AV fistulas must be confirmed by angiogram. Despite its high sensibility, arteriography may be inconclusive. van Dijk et al. ${ }^{7}$ described two patients whose angiograms did not reveal a spinal AV fistula, although the patients had classic signs and symptoms, both clinically and on MRI. Criscuolo et al. ${ }^{6}$ described two patients with diagnosis of Foix-Alajouanine syndrome and a negative spinal arteriography. Those $p$ re operative arteriographies were inconclusive, the same what happened with our patient. Likewise, the rewas no control exam at postoperative period.

When a patient presents a subacute clinical pictu re, correlated to venous congestion phase, the remission of the symptoms can be placed by intradurally surgical division of the shunting vein to the venous plexus. However, the potential for a reversal of this process of vascular lesion, including surgical stripping of the dorsal veins of the spinal cord has been advocated. At these cases, the surg e ry often led to clinical deterioration due to total lack of spinal cord normal venous drainage. At our case report, slight progressive recuperation on postoper a- tive period corroborated to the arterializated venous plexus origin, and proper surgical fistula division.

Criscuolo et al. ${ }^{6}$ and Wirth et al. ${ }^{4}$ emphasized the futility of treating patients with thrombosed AV fistula, as they considered it an end-stage process without hope of useful recovery of function. This is an argument against our case report. Some authors describe similar postoperative results achieved by endovascular embolization by liquid adhesive embolics. Therefore, despite of some controversies, the su rgical proce du re is the standard treatment, preventing clinical deterioration. Improvements are often possible to some extent.

In conclusion, spinal arteriovenous malform at ion has been associated with what has been known as Foix-Alajouaine syndrome. The clinical picture is a subacute pro g ressive myelopathy. The MAV clinical high suspicion must led us to an early surgical conduct to patient benefit. Arteriography and MRI are sensitive diagnostics tools to vascular alterations, but can be inconclusive at some point.

\section{REFERENCES}

1. Foix $C$, Alajouanine T. La myélite nécrotique subaigue. Rev Neurol (Paris) 1926;2:1-42.

2. Lhermitte J, Friboury-Blanc A, Kyriaco N. La gliose angéio-hyperthrophique de la moelle épinière (myélite nécrotique de Foix-Alajouanine). Rev Neurol (Paris) 1931;2:37-53.

3. Pia HW, Vogelsang H.Diagnose und Therapie spinaler Angiome. Dtsch Z Nervenheilkd 1965;187:74-96.

4. Wirth FP Jr, Post KD, Di Chiro G, Doppman JL, Ommaya AK. FoixAlajouanine disease. Spontaneous thrombosis of a spinal cord arteriovenous malformation: a case report. Neurology 1970;20:1114-1118.

5. Tobin WD, Layton DD. The diagnosis and natural history of spinal cord arteriovenous malformations. Mayo Clin Proc 1976; 51:637-646.

6. Criscuolo GR, Oldfield EH, Doppman JL. Reversible acute and subacute myelopathy in patients with dural arteriovenous fistulas: Foix-Alajouanine syndrome reconsidered. J Neurosurg 1989;70:354-359.

7. Van Dijk JMC, TerBrugge KG, Willinsky RA, et al. Multidisciplinary management of spinal dural arterovenous fistulas: clinical presentation and long-term follow-up in 49 patients. Stroke 2002;33:1578-1583.

8. Rosemblum N, Oldfield EH, Doppman JL, et al. Spinal arteriovenous malformations: a comparison of dural arteriovenous fistulas and intradural AVM's in 81 patients. J Neurosurg 1987;67:795-802.

9. Khurana VG, Perez-Terzic CM, Petersen RC, et al. Singing paraplegia: a distintictive manifestation of a spinal dural arteriovenous fistula. Neurology 2002;58:1279-1281. 